\title{
Water and Sanitation Services Public Policy and Management
}

Editado por José Esteban Castro e Léo Heller

C mo retratam os editores, a provisão adequada de serviços de abastecimento de água e esgotamento sanitário continua a ser um requisito essencial para a promoção e proteção da saúde e a manutenção das condições básicas de vida, constituindo-se a universalização sustentável desses serviços em escala global, um dos maiores desafios desse início de século 21. Embora nas últimas quatro décadas tenha acontecido um razoável avanço tecnológico nessa área, uma grande parcela da população mundial ainda encontra-se excluída do acesso a serviços de qualidade, cujas iniquidades representam um dilema ético para a comunidade internacional.

A formulação e a implementação de políticas públicas e a gestão dos serviços de abastecimento de água e de esgotamento sanitário têm, reconhecidamente, papel central na ampliação dos benefícios à população. Mas, apesar da importância desses temas, a comunidade acadêmica brasileira tem dispensado pouca atenção aos mesmos, observando-se a mesma fragilidade na literatura internacional. Análises cujo foco referencial parta das necessidades da política pública e da gestão em saneamento básico têm sido pouco frequentes.

Do lado dos formuladores governamentais das políticas da área, muitas vezes prevalecem concepções pautadas por referenciais arbitrários e com pouca consistência teórica, o que pode conduzir a resultados de baixa efetividade.

Dessa forma, um esforço para a construção teórica mais crítica e fundamentada sobre o tema e para a avaliação de experiências empíricas, com consistência metodológica, pode contribuir para uma maior qualificação da formulação na área, o que poderá resultar em políticas públicas mais orientadas pelos interesses da população, aumentando a sua efetividade.

O livro editado pelos Professores José Esteban Castro (Newcastle University, United Kingdom) e Léo Heller (Universidade de Federal de Minas Gerais, Brasil), lançado pela Earthscan no Reino Unido e nos Estados Unidos da América, em abril de 2009, traz uma excelente contribuição aos temas anteriormente levantados, sendo composto de duas partes: a primeira sobre Dimensões Teórica e Conceitual, com 10 capítulos; e a segunda, sobre Experiências de Países e Regiões, com 11 capítulos, escritos por 35 professores e pesquisadores de diversos países e continentes, inclusive os editores da publicação.

É estruturado a partir de temáticas previamente definidas pelos editores, as quais possibilitaram a produção de uma estrutura comum às diferentes contribuições, embora os pressupostos do livro sejam de responsabilidade dos editores, não sendo completamente compartilhadas por todos os autores de capítulos. Como primeiro pressuposto, os editores assumem que políticas de abastecimento de água e de esgotamento sanitário devem ser orientadas pelo princípio que esses serviços constituem um direito de cidadania, sendo obrigação do Estado garantir o seu acesso universal. Como segundo pressuposto, assumem que política pública e gestão no campo do abastecimento de água e esgotamento sanitário dependem das configurações históricas específicas e das condições físico-natural, sócio-econômico, política e cultural de cada país e região, havendo grandes diferenças entre e dentro de países e regiões quanto às condições sócio-econômicas que estabelecem as bases para a organização e distribuição dos serviços.

Além desses pressupostos, a estrutura do livro indica que os serviços de abastecimento de água e esgotamento sanitário necessitam ser analisados sob a dimensão da política pública. Incorpora ainda, a dimensão da gestão que se refere à organização dos serviços, que, dependendo do modelo adotado, pode ser implementado ao nível local, regional ou nacional. O livro explora os principais paradigmas para os diferentes tipos de organização/prestação dos serviços.

Por outro lado, visando oferecer elementos para uma comparação, o livro examina um número de cases de países desenvolvidos e em desenvolvimento, na Europa, Américas, Ásia e África.

O livro traz uma pioneira, inovadora e inestimável contribuição teórico-conceitual às políticas públicas e à gestão dos serviços de abastecimento de água e de esgotamento sanitário, sendo leitura obrigatória para formuladores e implementadores de políticas públicas, gestores públicos, legisladores, tomadores de decisão e pesquisadores interessados nos temas.

A edição em português encontra-se no prelo, devendo ser lançada no Brasil em breve.

\section{Comentários realizados por Luiz Roberto Santos Moraes Coordenador da coluna Livros: Cícero Onofre de Andrade Neto}

A sessão "Livros", que a cada edição traz resumos comentados sobre livros de interesse na área, tem como principal objetivo permitir que o leitor, de forma rápida, se atualize e conheça o que há disponível no mercado editorial. As contribuições deverão ser encaminhadas para: resa@abes-dn.org.br 